\title{
Psychological Mechanisms of Understanding Contemporary Texts of American Writers
}

\section{Психологічні механізми розуміння сучасних текстів американських письменників}

\section{Nataliia Mykhalchuk}

Dr. in Psychology, Professor, Rivne State University of the Humanities, Rivne (Ukraine)

ORCID ID: https://orcid.org/0000-0003-0492-9450

Researcher ID: http://www.researcherid.com/rid/A-9440-2019

Scopus Author ID: 57214227898

E-mail: natasha1273@ukr.net

\section{Наталія Михальчук}

Доктор психологічних наук, професор, Рівненський державний гуманітарний університет, м. Рівне (Україна)

\section{Iryna Koval}

Ph. D. in Psychology, Assistant Professor, Department of Foreign Language Education and Intercultural Communication, Khmelnytskyi National University, Khmelnytskyi (Ukraine)

ORCID ID: https://orcid.org/0000-0002-2048-0000

Researcher ID: http://www.researcherid.com/rid/B-2173-2019

E-mail: iryna-koval@i.ua

\section{Ірина Коваль}

Кандидат психологічних наук, доцент, доцент кафедри іншомовної освіти і міжкультурної комунікації, Хмельницький національний університет, м. Хмельницький (Україна)

Address for correspondence, e-mail: kpnu_lab_ps@ukr.net Copyright: (C) Mykhalchuk Nataliia, Koval Iryna

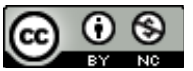

The article is licensed under CC BY-NC 4.0 International (https://creativecommons.org/licenses/by-nc/4.0/) 
DOI: https://doi.org/10.32626/2227-6246.2021-51

The author's contribution: Mykhalchuk N. $-50 \%$, Koval I. $-50 \%$.

Авторський внесок: Михальчук Н. $-50 \%$, Коваль І. $-50 \%$.

\section{ABSTRACT}

The purpose of the article is to define the style of the novel as complex and multi-layered process, and to propose psychological mechanisms of understanding contemporary texts of American writers.

The following theoretical methods of the research were used to solve the tasks formulated in the article: a categorical method, structural and functional methods, the methods of the analysis, systematization, modeling, generalization.

The results of the research. The degree of closeness of such a secondary text to the source will depend on many factors - the level of human understanding of the source text, the expectations and attitudes of the reader, the level of reader's interests, reading goals and so on. The understanding of the text will include its division into relatively independent attitude in terms of actual content passages (text elements) with their subsequent regrouping in order to separate the main and the secondary context, the establishment of a hierarchy of meanings.

Conclusions. There were proposed psychological mechanisms of understanding contemporary texts of American writers. The first one is the mechanism of Decentralization: keeping in the minds of the reader of two contradictory ideas at the same time and while maintaining the ability to act, analyzing novels, creating their own stories, solving situations; overcoming personal egocentric manifestations; show tolerant, impartial attitude to the opinions and statements of communication partners; the transformation of the meaning of images, concepts, ideas, taking into account the author's own emotional and cognitive positions, points of view, actions, lifestyle of others; change of views and positions of the reader by comparison of own point of view with representations and positions of other people and others. The next one is the mechanism of Empathy: taking into account the nature of independently selected novels (romantic, realistic, philosophical ones) for psychological analysis; recognition of mental states of people depicted in novels (a plot, a portrait, music, painting, psycho-artistic situations); determination of emotional states of characters of novels, communication partners, congruence of behavior in non-standard-stimulating situations or situations of cognitive dissonance. And the third mechanism is the mechanism (c) Mykhalchuk Nataliia, Koval Iryna

DOI (article): https://doi.org/10.32626/2227-6246.2021-51.121-141 
of Reflection: the implementation of the relationships of the elements of a novel into a constructive system; substantiation of one's own attitude to a certain situation, its participants, identification of personal and situational determinants of the behavior of the subjects of this situation (including if these subjects are the author and the heroes of the novel).

Key words: psychological mechanisms of understanding the texts, the style of the novel, the mechanism of Decentralization, the mechanism of Empathy, the mechanism of Reflection.

\section{Introduction}

Today, one of the most important researches in the paradigm of psycholinguistics is the relationship between the syntactical design of the novel and the individual style of the author. The complex composition of the text includes: the selection of text's fragments, their organization, placement and the integration into the whole text structure which depends on the individual syntax of each writer. This individual syntax is the author's own way which denotes the selection and providing the definitions of methods which, in turn, apply using syntactic constructions by this author. The author defines his / her own image system, as well as events and situations, taking into account the genre of literature, chosen era, the ideological content.

The problem of studying the style of the novel was described in the researches of many scholars. Thus, the study of the individual style of the writer was presented in a lot of researches (Brédart, 1991; Mykhalchuk \& Kryshevych, 2019). Global scientific reviews of the problems of artistic style in relations to each language mean that the concept of style is multifaceted. Style is considered as a universal category, because in the history of linguistic and cultural development of each language this concept has acquired the description of art and its philological understanding. Researchers mean the style of the day, the style of direction and flow, the style of the writer and the style of a certain period of his / her novels (stories,

(C) Mykhalchuk Nataliia, Koval Iryna DOI (article): https://doi.org/10.32626/2227-6246.2021-51.121-141 
poetry), the style of the text's structure and the style of the text's individual elements. However, the most common in literature is the understanding of style as the individual creative manner, so called "creative face» of the individual manner of a writer (Гончарук \& Онуфрієва, 2018).

In contemporary psychology the emphasis is placed on the fact that style includes a lot of text's structures which are realized only at the textual level. Thus, a style is understood as a synonym of artistic direction or artistic trend. But more often this term describes the author's, individual style of writing, or such kind of idiosyncrasy (Crookes, 1989).

Artistic modeling of the reality is based on verbal communication, which was included into the text, usually had been involving penetration into the creative objective world of the artist of the text. Thus, scientists note that a piece of art transmits a small number of impulses and signals that can cause a whole set of detailed ideas that together create a picture of readers' ideas, and also this picture may be different for different readers (Blagovechtchenski, Gnedykh, Kurmakaeva, Mkrtychian, Kostromina \& Shtyrov, 2019).

Pointing out that the artistic model is always broader than its interpretation, some scientists focus on a single type of interpretation, without taking into account a set of numerous possible interpretations. Each model generates different interpretations, but also acts as a representation of a broader model, having been formed by the infinite number of other interpretations (Максименко, Ткач, Литвинчук \& Онуфрієва, 2019).

So, the purpose of this article is to define the style of the novel as complex and multi-layered process, and to propose psychological mechanisms of understanding contemporary texts of American writers.

\section{Methods of the research}

The following theoretical methods of the research were used to solve the tasks formulated in the article: a categorical C Mykhalchuk Nataliia, Koval Iryna

DOI (article): https://doi.org/10.32626/2227-6246.2021-51.121-141 
method, structural and functional methods, the methods of the analysis, systematization, modeling, generalization.

\section{Results and their discussion}

According to its structure, the style of the novel is complex and multi-layered, so there are four main functions of each text. The first factor is the creative process, the orientation of the writer on the relations to the reality, so called artistic tradition. Individual style is defined as a factor in each novel. It determines its existence as a complete artistic phenomenon and expresses the nature, the direction and a degree of aesthetic perception of the world by the reader. Style is a main factor in the artistic process and guides the writer in the development of art. In addition, style is a factor in artistic communication (between the author and the recipient) (Mykhalchuk \& Bihunova, 2019).

It is important in the psychological research that they clarify the concept of «individual style». According to N. Chepeleva each writer creates his / her own style, looking for original ways and means of implementing their ideas and images. Individual style is an indicator of the highest degree of the development of creative personality (Чепелєва, 2006).

There are different approaches according to the typology of individual style. Thus, some scientists distinguish between realistic and romantic types of creativity. It is also worth to note that the study of the typology of styles is a search for the relationships of different individual styles as the main components of the stylistic development of literature (Mykhalchuk \& Onufriieva, 2020). According to this idea M. Vovk, O. Emishyants, O. Zelenko, O. Drobot \& L. Onufriieva (2020) identify the following factors that are fundamental in the typology of stylistic differentiation: the role of the author's image in the novel and the degree of its presence in it, the similarity of composition and linguistic image, also selected details.

(C) Mykhalchuk Nataliia, Koval Iryna DOI (article): https://doi.org/10.32626/2227-6246.2021-51.121-141 
DOI: https://doi.org/10.32626/2227-6246.2021-51 2021. випУСК 51

The concept of individual style of the writer is determined by the type of the author's worldview and his / her own picture of the world. These factors determine the author's aesthetic consciousness. When studying a writer's style, scholars mostly use a deductive approach, when firstly it constants and dominants of a certain piece of art or a trend, then these features are fixed in the researches of different writers which belong to a certain style in literature, and it is traced how they are reflected in a particular text.

The inductive approach in the researches of the author's style involves the analysis from the individual style to a general definition of it, which requires focusing on a particular text, on the paradigm of style of a particular text, and then on the manner of writing of the writer in general. Taking into account that fact that each author is a representative of a certain direction, the material in the study of the problem of the author's style should be a specific artistic work carrier and the expression of stylistic patterns.

The subjective intentions of the author, his / her inner world and psychological features significantly affect the understanding, systematization, aesthetic and creative selection of psycholinguistic elements of the content of author's expressions. These requirements in our research are the psycholinguistic basis of the creative process of writing the novels. Some scientists noted that theories about the connection of a word as a sign with what it means are based on psychological explanations - so called associations, which provided the connections of cause and effect, means and ends, general agreements. So, the impression of the word does not depend on its specific features, and from the ways and means of emotional expressions of feelings and emotions (Cilibrasi, Stojanovik, Riddell \& Saddy, 2019). Recognizing the word as the most powerful weapon of psychological cognition, the scientists note that a style of the text consists not only of individual, inherent in the text of the author ideas, but also it includes historical, cultural, social (c) Mykhalchuk Nataliia, Koval Iryna

DOI (article): https://doi.org/10.32626/2227-6246.2021-51.121-141 
factors. This motivates the importance of studying not only the meaning of the word in the novel, but also its nuances, because psychological factors, in addition to lexical meaning of the texts, may have semantic or emotional layers, which reflect individual understanding and attitude of the phenomena of objective reality, special expressiveness of each writer.

Valuable for stylistics of individual artistic language and stylistics of fiction there are the researches of N. Mykhalchuk \& E. Ivashkevych (2019). The scientist firstly put forward the idea of the system of the novel, and provided the main system, which helps to form some elements having been identified the author's word.

There are some categories of individual style of the writer, such as: a category of style which determines a certain period of creativity and a category of style of a novel. The individual style of the writer reflects the peculiarities of his / her artistic thinking. The style of a creative period is changed in different periods of the writer's life. The unique stylistic integrity that is characterized by novels distinguishes them from other pieces of art of the same writer.

The systemic nature of the individual style is based on the connection between the language and thinking, on the formation of a psychological picture of the world, which combines some general and individual aspects of understanding. Knowledge of the individual style of writing involves identifying not only the formal differences of this style from another one, but also a great penetration into the style of a novel, establishing the content of the text's form as the important component of the individual style. The idiosyncrasy of a writer has a close connection to a literary language, its folklore, also oral and literary traditions.

To determine the individual style of the writer it is necessary to conduct a linguistic analysis of the novel, during which data on the use of language tools, features of their combination and functioning in specific texts of the author are se-

(C) Mykhalchuk Nataliia, Koval Iryna DOI (article): https://doi.org/10.32626/2227-6246.2021-51.121-141 
DOI: https://doi.org/10.32626/2227-6246.2021-51 2021. випуск 51

lected. This information allows us to draw conclusions about the idiolect and idiosyncrasy of the writer. Thus, the author's style includes a number of morphological, lexical and syntactical units of a language that the writer chooses to implement the author's general idea.

The individual syntax of the writer is one of the main features of the expression of the author's style in the novel. The structure of the sentences within the text is closely connected with the author's worldview, the general life position of the author. It is through a whole set of sentences that one can trace how the writer interprets the surrounding reality.

The author's depiction of how the characters perceive the world around them is through authorial and indirect language. While trying to express the main thing in a small piece of text, the author can resort to generalization, omitting even the most interesting details. Choosing certain forms of sentences' organization, the writer can emphasize on the nature of the image of the object, emotional and rhythmic tasks, existing traditions and genre patterns.

One of the author's methods is to use commentary sentences, which are typical for the syntactic structure of spoken language. Among the huge number of structural and semantic types of connecting constructions, each author chooses those ones that in the best way can correspond to the author's depicting system. Comments of the sentences are the means of artistic and pictorial expression, according to the author can perform a number of stylistic tasks. In addition, the emotional content of fiction can be achieved through the use of elliptical sentences and other linguistic means.

In the research of the author's syntax, it is also important to pay attention to the frequency of use of certain language forms in each novel. At the same time, a considerable attention has to be paid to the research of sentence size and the identification of significant grammatical differences, characteristics of different types of texts, including artistic ones.

(C) Mykhalchuk Nataliia, Koval Iryna

DOI (article): https://doi.org/10.32626/2227-6246.2021-51.121-141 
The growth of the communicative depth of the message (due to the communicative secondary patterns) can be onestaged, two- and three-staged. This is observed, for example, in novels, where each letter is quoted the degree of communicative deepening, which in turn includes someone's quote (the second degree of deepening of understanding).

The researches of the specifics of novels, made by us, allowed us to claim that the longest sentences are characteristic of the author's speech, and the shortest ones can be presented in the dialogues. In addition, we can note the following conclusion: the longer the author's statements are, the longer the sentences of the characters of the novel. We can also assume that the length of the sentence is directly related to its content, distribution and stylistic functions of the novel, as there is a hypothesis that is the most specific in the content of the novel, there are the shorter the sentences in it.

Taking into account the length of the sentences, within the author's discourse there are two types of variability, so called inter-author, which is a reflection of the uniqueness and features of the author's idiolect and intra-author, which indicates the evolution of the author's idiostyle. It is internally that the author's variability is taken into account during the statistical study of individual author's artistic speech.

Investigating textual formations, we introduce the concept of «supporting text». We claim that the communicative inequality of the main and auxiliary components of the text structure can be traced in the structure of the meta-text. On the one hand, the main text is a single graphic array, fully or predominantly placed in the structure of the text. Graphic arrays of auxiliary messages, on the other hand, are always separated from the main text paradigm and from each text component.

The font in these messages which has been printed is usually different from the font of the main text and indicates the subordinate status of the corresponding fragment. The same applies to the placement of the graphic text structure of each

(C) Mykhalchuk Nataliia, Koval Iryna DOI (article): https://doi.org/10.32626/2227-6246.2021-51.121-141 
page - or at the bottom after the main text (a footnote, a note), or with enlarged left or right margin (an epigraph, a dedication, the annotation).

The peculiarities of the use of stylistic devices in the novel during the study of the specifics of the author's style draw our attention. Stylistic reception, according to the author, is always a realization of the potential of a common language. However, it correlates general and individual context of the text's paradigm. Stylistic technique, in terms of its specific implementation, has its individual character. The individuality of the stylistic reception, the uniqueness of its psychological use was the reason that it began to be considered as a deviation from the linguistic norm. This is explained by the fact that in the language of fiction the authors often use techniques of syntactic communication, which are typical for spoken language and they are considered to be deviations from the norms of written speech.

However, we think that the person use the stylistic techniques which can not be considered as a deviation from the system of natural language. This is a certain change in the paradigm of individual features of the stylistic reception through the category of «natural». That is why it is possible to distinguish structural and semantic types of each stylistic device, also the construction of its model.

Each stylistic device can include two levels: the level of language structure and the level of a separate message. At the structural level, stylistic reception is considered by us as a type of a message in which the sense of the idea is generalized, typified features of stylistic receptions are analyzed. The identification of patterns is in the structural and semantic organization of stylistic reception (the construction of individual message according to identified generalized types of features), study of the person, unique characteristics of stylistic reception. The analysis of specific application of stylistic reception is the task of literary stylistics.

(C) Mykhalchuk Nataliia, Koval Iryna

DOI (article): https://doi.org/10.32626/2227-6246.2021-51.121-141 
In addition, when analyzing the individual style of the writer, it is necessary to refer to a specific literary material. In such a way there is no author who is the representative of any direction throughout the text. Thus, the material in the study of individual style of the author should be a specific activity as its carrier and expression. A better idea of individual style can be obtained by analyzing several texts of the writer, establishing intertextual connections between them.

Thus, the analysis of the novel allows us to trace the peculiarities of the author's selection of certain sentence structures, stylistic devices and other means that distinguish this text of the author. The research of the author's style and linguistic means of the expression of his / her worldview involves a step-by-step analysis of the novel, taking into account general stylistic features of the text, as well as the research of units at all levels of the language.

Psychological analysis of the novel involves the study of stylistic features of the text at all levels. Psycho-stylistic analysis of novels of $\mathrm{R}$. Bach will allow us more thorough study of the author's philosophical worldview in his famous pieces of art.

The allegory of the writer, which can be traced in the most of his novels, is similar to the manner of the Impressionists, which allows the reader to determine what is important. In addition a free style of the author allows us to combine different meanings of statements, to draw parallels. The reader can give his / her own definitions of evaluative words.

The study shows that in the novels of $R$. Bach there are often examples of alliteration. Planned multiple repetition of the same sounds or sound combinations help the reader to understand means of increasing expressiveness of the novel:

But Jonathan Livingston Seagull, unashamed, stretching his wings again in that trembling hard curve - slowing, and stalling once more - was no ordinary bird (Bach, 2003: 9);

(C) Mykhalchuk Nataliia, Koval Iryna DOI (article): https://doi.org/10.32626/2227-6246.2021-51.121-141 
DOI: https://doi.org/10.32626/2227-6246.2021-51 2021. випУСК 51

Even his parents were dismayed as Jonathan spent whole day alone, making hundreds of low-level glides, experimenting (Bach, 2003: 9);

From a thousand feet, flapping his wings as hard as he could, he pushed over into a blazing steep dive toward the waves... (Bach, 2003: 11);

Ten times he tried, and all ten times he passed through seventy miles per hour... (Bach, 2003: 11);

He pushed wearily away from the dark water and flew toward the land, grateful for what he had learned about work-saving low altitude (Bach, 2003: 14).

The main prerequisite for studying the sound system of the text is in that fact that sounds are "carriers» of information, its "hidden content». There is a hypothesis that there is a certain correlation between the meaning of a word and its sound. That is why the author of the novel consciously uses sound schemes to enhance the impact of the text on the reader.

One of the features of novels of $R$. Bach is the use of numerous graphic means of punctuation and spelling, which distinguishes his pieces of art among others. In analyzed texts the writer often uses numerous words and the whole sentences, printed by capital letters, italics to highlight key phrases, as well as sentences with incomplete thoughts. It is obvious that in this way he emphasizes the importance of expressed thoughts, their emotionality, draws the reader's attention to them, makes him / her think about the deep meaning of the statements:

Dark! The hollow voice cracked in alarm. Seagulls never fly in the dark (Bach, 2003: 14);

Short wings! A falcon's short wings! (Bach, 2003: 15);

A seagull at two hundred miles per hour! (Bach, 2003: 18);

I am a perfect, unlimited gull! (Bach, 2003: 37);

Jonathan made a screen of delight, the first sound he had made since he had left Earth. IT WORKS! (Bach, 2003: 38);

A ... a ... mosquito does that! (Bach, 2003: 43);

(C) Mykhalchuk Nataliia, Koval Iryna

DOI (article): https://doi.org/10.32626/2227-6246.2021-51.121-141 
DOI: https://doi.org/10.32626/2227-6246.2021-51

2021. випУСК 51

YES, I WANT TO FLY! (Bach, 2003: 45);

He lives! He that was dead lives! (Bach, 2003: 59);

Me leading? What do you mean, me leading? $M e$ ? Jon, I'm just a plain seagull, and you you're... (Bach, 2003: 62);

«MAN!» he shouted a second before the next dynamite went off, «I'M REALLY LEARNING A LOT ABOUT METEOROLOGY!» (Bach, 2003: 104);

"I learned a tremendous amount," he had written (Bach, 2003: 112);

"ONE MORE TIME? REMEMBER THIS IS A HUMAN LIFE YOU'RE DEALING WITH!» (Bach, 2003: 25);

Also discussed at the Briefing, I'm sure, was You've Got To Be A Mighty Good Aviator To Land Old Biplanes In A Crosswind On A Hard-Surface Runway (Bach, 2003: 45);

Miss that Big Briefing In The Sky, and you have to find out for yourself about flying coast to coast in old airplanes (Bach, 2003: 52);

One of the primal points covered in the Big Briefing apparently was that People Don't Fly Old Airplanes From Coast To Coast. People In Their Right Minds, that is. Then along comes old Bach, who misses the Briefing (Bach, 2003: 45).

By using italics and changing the font size of the letters, the logical or emotional reinforcement of the thoughts having been expressed in the text carried out. In this way, keywords are highlighted, which indicate their importance for the development of the plot of the novel. The selection of single words or sentences indicates the special emotionality with which it is pronounced by the character. Graphical stylistic devices from the text give us general visual expressiveness.

As for the sentences with an incomplete thought, they usually convey the pause of the characters' speech, their indecision, doubts or excitement, which can be traced at the beginning, in the middle and at the end of the sentences.

He narrowed his eyes in fierce concentration, held his breath, forced one ... single ... inch ... of ... curve (Bach, 2003: 7);

(C) Mykhalchuk Nataliia, Koval Iryna DOI (article): https://doi.org/10.32626/2227-6246.2021-51.121-141 
DOI: https://doi.org/10.32626/2227-6246.2021-51 2021. випУСК 51

"...one day, Jonathan Livingston Seagull, you shall learn that irresponsibility does not pay» (Bach, 2003: 22);

"Chiang...» he said, a little nervously (Bach, 2003: 33);

"At last you've got the idea,» Chiang said, "but your control needs a little work...» (Bach, 2003: 37);

"Help me,» he said very quietly, speaking in the way that the dying speaks. "I want to fly more than anything else in the world...» (Bach, 2003: 54);

«... saw them flying low over Nilson's place there, and a figure was in trouble» (Bach, 2003: 107);

"If you had taken the time to examine my logbook," I said icily, "you would have seen that..." (Bach, 2003: 126 );

«Well, of course. I could turn...» (Bach, 2003: 127).

So, the text always consists of words that are carriers of information. Virtually any neutral word, depending on the speech or situational context in which it is used, can take on different meanings. It is known that in addition to the basic, subject-logical meaning, words also have a connotative meaning. Depending on the features of this meaning, there are words of high stylistic level; words are used in literary language and vocabulary is used in the paradigm of colloquial language.

We also consider the research of $\mathrm{N}$. V. Chepeleva to be the basis for distinguishing psychological mechanisms of the reader's comprehension of novels. The latter is carried out by forming a certain subject-structural code, which allows to record the content of the text in the form of a generalized semantic scheme by the reader. We also took into account the theory of N. V. Chepeleva on the creation in the mind of the recipient of a semantic skeleton, which, if it is necessary, can unfold into a complete message. The degree of closeness of such a secondary text to the source will depend on many factors - the level of human understanding of the source text, the expectations and attitudes of the reader, the level of reader's interests, reading goals and so on. Understanding the text C Mykhalchuk Nataliia, Koval Iryna

DOI (article): https://doi.org/10.32626/2227-6246.2021-51.121-141 
will include its division into relatively independent attitude in terms of actual content passages (text elements) with their subsequent regrouping in order to separate the main and the secondary context, the establishment of a hierarchy of meanings (Чепелєва, 2006).

\section{Conclusions}

In such a way we proposed psychological mechanisms of understanding contemporary texts of American writers. They are:

1. The mechanism of Decentralization:

- keeping in mind of the reader two contradictory ideas at the same time and while maintaining the ability to act, analyzing novels, creating their own stories, solving situations;

- olerant, impartial attitude to the opinions and statements of communication partners; the transformation of the meaning of images, concepts, ideas, taking into account the author's own emotional and cognitive positions, points of view, actions, lifestyle of others; changing of views and positions of the reader by comparison of own point of view with representations and positions of other people;

- conducting parity dialogues: the internal one (the ability to appeal to one's own point of view) and the external dialogue (in the context of novels, in the process of solving problematic creative tasks and situations during their discussion in conversations, discussions, dialogues), psychological readiness for cooperation.

2. The mechanism of Empathy:

- taking into account the nature of independently selected novels (romantic, realistic, philosophical ones) for psychological analysis;

- recognition of mental states of people depicted in novels (a plot, a portrait, music, painting, psycho-artistic situations); - determination of emotional states of characters of novels, communication partners, congruence of behavior in

(C) Mykhalchuk Nataliia, Koval Iryna DOI (article): https://doi.org/10.32626/2227-6246.2021-51.121-141 
DOI: https://doi.org/10.32626/2227-6246.2021-51 2021. виПуск 51

non-standard-stimulating situations or situations of cognitive dissonance.

3. The mechanism of Reflection:

- the implementation of the relationships of the elements of a novel into a constructive system; substantiation of one's own attitude to a certain situation, its participants, identification of personal and situational determinants of the behavior of the subjects of this situation (including if these subjects are the author and the heroes of the novel).

\section{Literature}

Гончарук Наталія, Онуфрієва, Ліана. Психологічний аналіз рівнів побудови комунікативних дій. Psycholinguistics. Психолінгвістика. Психолингвистика. 2018. Вип. 24 (1). С. 97-117. DOI 10.31470/2309-1797-2018-24-1-97-117.

Максименко С., Ткач Б., Литвинчук Л., Онуфрієва Л. Нейропсихолінгвістичне дослідження політичних гасел із зовнішньої реклами. Psycholinguistics. Психолінгвістика. Психолингвистика. Переяслав-Хмельницький : ФОП Домбровська Я. М., 2019. Вип. 26 (1). C. 246-264. DOI 10.31470/2309-1797-2019-26-1-246-264. URL : https://psycholing-journal.com/index.php/journal/article/view/ 715 .

Чепелєва Н. В. Смислова структура тексту як чинник його розуміння. Актуальні проблеми психологї̈ / за ред. С. Д. Максименка, М.-Л. А. Чепи. Київ : Міленіум, 2006. Т. 9, ч. 1. С. 113-123.

Bach, R. (2003). Jonathan Livingston Seagull. Москва : Айрис Пресс. $103 \mathrm{c}$.

Blagovechtchenski, E., Gnedykh, D., Kurmakaieva, D., Mkrtychian, N., Kostromina, S., \& Shtyrov, Y. (2019). Transcranial direct current stimulation (tDCS) of Wernicke's and Broca's areas in studies of language learning and word acquisition. Journal of Visualized Experiments, (pp. 37-59). URL : https://doi.org/10.3791/59159.

Brédart, S. (1991). Word interruption in self-repairing. Journal of Psycholinguistic Research, 20, 123-137. URL : https://doi.org/10.1007/ bf01067879.

Cilibrasi, L., Stojanovik, V., Riddell, P., \& Saddy, D. (2019). Sensitivity to Inflectional Morphemes in the Absence of Meaning: Evidence from a Novel Task. Journal of Psycholinguist Research, 48, 747-767. URL : https://doi.org/10.1007/s10936-019-09629-y.

(C) Mykhalchuk Nataliia, Koval Iryna

DOI (article): https://doi.org/10.32626/2227-6246.2021-51.121-141 http://journals.uran.ua/index.php/2227-6246 
Crookes, G. (1989). Planning and interlanguage variation. Studies in Second Language Acquisition, 11, 367-383. URL : https://doi.org/10.1017/ s0272263100008391.

Mykhalchuk, N., \& Bihunova, S. (2019). The verbalization of the concept of «fear" in English and Ukrainian phraseological units. Cognitive Studies |Études cognitives, 19, 11. Warsaw (Poland). URL : https:// doi.org/10.11649/cs.2043.

Mykhalchuk, N., \& Ivashkevych, E. Psycholinguistic Characteristics of Secondary Predication in Determining the Construction of a Peculiar Picture of the World of a Reader. Psycholinguistics. Psykholinhvistyka. Psiholingvistika. Переяслав-Хмельницький : ФОП Домбровська Я. М., 2019. Вип. 25 (1). С. 215-231. DOI 10.31470/2309-17972019-25-1-215-231.

Mykhalchuk, Nataliia, \& Kryshevych, Olga. The peculiarities of the perception and understanding of Sonnets written by W. Shakespeare by the students of the Faculty of Foreign Languages. Psycholinguistics. Психолінгвістика. Психолингвистика: збірник наукових праць. Серія: Психологія. Переяслав-Хмельницький : ФОП Домбровська Я. М., 2019. Вип. 26 (1). С. 265-285. DOI 10.31470/2309-17972019-26-1-265-285.

Mykhalchuk, Nataliia, \& Onufriieva, Liana. Psycholinguistic features of representation of emotions by the concept of «Fear». Проблели сучасної психологї: Зб. наук. праць Кам'янець-Подільського національного університету ілені Івана Огієнка, Інституту психології ілені Г. С. Костюка НАПН України. Кам'янець-Подільський, 2020. Вип. 48. С. 206-227.

Vovk, M., Emishyants, O., Zelenko, O., Drobot, O., \& Onufriieva, L. (2020). Psychological Features of Experiences of Frustration Situations in Youth Age. International Journal of Scientific \& Technology Research, 8 (01), 920-924. URL : http://www.ijstr.org/paperreferences.php?ref=IJSTR-0120-28117.

\section{References}

Honcharuk, Nataliia, \& Onufriieva, Liana (2018). Psykholohichnyi analiz rivniv pobudovy komunikatyvnykh dii [Psychological analysis of the levels of construction of communicative actions]. Psycholinguistics. Psykholinhvistyka. Psikholingvistika - Psycholinguistics. Psycholinguistics. Psycholinguistics, 24 (1), 97-117. DOI 10.31470/23091797-2018-24-1-97-117 [in Ukrainian].

Maksymenko, S., Tkach, B., Lytvynchuk, L., \& Onufriieva, L. (2019). Neiropsykholinhvistychne doslidzhennia politychnykh hasel iz zovnish-

(C) Mykhalchuk Nataliia, Koval Iryna

DOI (article): https://doi.org/10.32626/2227-6246.2021-51.121-141 
DOI: https://doi.org/10.32626/2227-6246.2021-51

noi reklamy [A neuropsycholinguistic research of political slogans from outdoor advertising]. Psycholinguistics. Psykholinhvistyka. Psikholingvistika - Psycholinguistics. Psycholinguistics. Psycholinguistics, 26 (1), 246-264 [in Ukrainian].

Chepeleva, N. V. (2006). Smyslova struktura tekstu yak chynnyk yoho rozuminnia [The semantic structure of the text as a factor in its understanding]. S. D. Maksymenko, M.-L. A. Chepa (Eds.). Aktualni problemy psykholohii - Current problems of Psychology, 9 (1), 113-123. Kyiv : Millennium [in Ukrainian].

Bach, R. (2003). Jonathan Livingston Seagull. Moskva : Iris Press.

Blagovechtchenski, E., Gnedykh, D., Kurmakaieva, D., Mkrtychian, N., Kostromina, S., \& Shtyrov, Y. (2019). Transcranial direct current stimulation (tDCS) of Wernicke's and Broca's areas in studies of language learning and word acquisition. Journal of Visualized Experiments, (pp. 37-59). Retrieved from https://doi.org/10.3791/59159.

Brédart, S. (1991). Word interruption in self-repairing. Journal of Psycholinguistic Research, 20, 123-137. Retrieved from https://doi. org/10.1007/bf01067879.

Cilibrasi, L., Stojanovik, V., Riddell, P., \& Saddy, D. (2019). Sensitivity to Inflectional Morphemes in the Absence of Meaning: Evidence from a Novel Task. Journal of Psycholinguist Research, 48, 747-767. Retrieved from https://doi.org/10.1007/s10936-019-09629-y.

Crookes, G. (1989). Planning and interlanguage variation. Studies in Second Language Acquisition, 11, 367-383. Retrieved from https://doi.org/ $10.1017 / \mathrm{s} 0272263100008391$.

Mykhalchuk, N., \& Bihunova, S. (2019). The verbalization of the concept of «fear» in English and Ukrainian phraseological units. Cognitive Studies | Études cognitives, 19, 11. Warsaw (Poland). Retrieved from https://doi.org/10.11649/cs.2043.

Mykhalchuk, N., \& Ivashkevych, E. (2019). Psycholinguistic Characteristics of Secondary Predication in Determining the Construction of a Peculiar Picture of the World of a Reader. Psycholinguistics. Psykholinhvistyka. Psikholingvistika - Psycholinguistics. Psycholinguistics. Psycholinguistics, 25 (1), 215-231. Pereiaslav-Khmelnytskyi : FOP Dombrovska Ya. M. DOI 10.31470/2309-1797-2019-25-1-215231.

Mykhalchuk, Nataliia, \& Kryshevych, Olga (2019). The peculiarities of the perception and understanding of Sonnets written by W. Shakespeare by the students of the Faculty of Foreign Languages. Psycholinguistics. Psykholinhvistyka. Psiholingvistika - Psycholinguistics. Psycholinguistics. Psycholinguistics, 26 (1), 265-285. Pereiaslav-Khmel-

(C) Mykhalchuk Nataliia, Koval Iryna

DOI (article): https://doi.org/10.32626/2227-6246.2021-51.121-141 http://journals.uran.ua/index.php/2227-6246 
nytskyi : FOP Dombrovska Ya. M. DOI 10.31470/2309-1797-2019. 26-1-265-285.

Mykhalchuk, Nataliia, \& Onufriieva, Liana (2020). Psycholinguistic features of representation of emotions by the concept of «Fear». Problemy suchasnoi psykholohii: Zb. nauk. prats Kamianets-Podilskoho natsionalnoho universytetu imeni Ivana Ohiienka, Instytutu psykholohii imeni H. S. Kostiuka NAPN Ukrainy - Problems of Modern Psychology: Collection of research papers of Kamianets-Podilskyi National Ivan Ohiienko University, G. S. Kostiuk Institute of Psychology of the National Academy of Educational Sciences of Ukraine, 48, 206-227. Vovk, M., Emishyants, O., Zelenko, O., Drobot, O., \& Onufriieva, L. (2020). Psychological Features of Experiences of Frustration Situations in Youth Age. International Journal of Scientific \& Technology Research, 8 (01), 920-924. Retrieved from http://www.ijstr.org/paperreferences.php?ref=IJSTR-0120-28117.

Михальчук Наталія, Коваль Ірина. Психологічні механізми розуміння сучасних текстів американських письменників

\section{АНОТАЦІЯ}

Mema cmammi - запропонувати психологічні механізми розуміння сучасних текстів американських письменників через визначення стилю роману як складного і багатошарового процесу.

Для розв'язання поставлених у роботі завдань використано такі теоретичні методи дослідження: категоріальний, структурно-функціональний, аналіз, систематизація, моделювання, узагальнення.

Результати дослідження. Показано, що ступінь близькості вторинного тексту до вихідного залежатиме від багатьох чинників - рівня розуміння людиною вихідного тексту, очікувань і настановлень читача, рівня читацьких інтересів, цілей читання тощо. Розуміння тексту включатиме його розчленування на відносно самостійні щодо фактичного змісту уривки (текстові елементи) з наступним їх перегрупуванням із метою виокремлення головного та другорядного, тобто встановлення ієрархії смислів.

Висновки. Запропоновано психологічні механізми розуміння сучасних текстів американських письменників. Першим є механізм децентрації: утримування в свідомості суб'єкта двох суперечливих ідей одночасно $i$ при цьому - збереження можливості діяти, аналізуючи художні твори; створення власних оповідань, розв'язання ситуацій; подолання особис-

(C) Mykhalchuk Nataliia, Koval Iryna DOI (article): https://doi.org/10.32626/2227-6246.2021-51.121-141 
DOI: https://doi.org/10.32626/2227-6246.2021-51 2021. випуск 51

тісних егоцентричних проявів; толерантне, неупереджене ставлення до думок і висловлювань партнерів по спілкуванню; перетворення смислу образів, понять, уявлень з урахуванням власної емоційно-когнітивної позиції, точок зору, вчинків, способу життя інших; зміна поглядів і позицій читача при зіставленні власної точки зору з уявленнями і позиціями інших людей тощо. Наступним є механізм емпатії: характер самостійно обраних для психологічного аналізу творів художньої літератури (романтичні, реалістичні, фрілософрькі); розпізнавання психічних станів людей, зображених у творах мистецтва (сюжет, портрет, музика, картина, психомистецька ситуація); визначення емоційних станів персонажів літературного твору, партнерів по спілкуванню; конгруентність поведінки у нестандартно-стимулюючих ситуаціях чи ситуаціях когнітивного дисонансу. I, нарешті, останнім механізмом є механізм рефрлексії: здійснення взаємозв'язку елементів літературного твору в конструктивну систему; обгрунтування власного ставлення до певної ситуації, ії учасників, виявлення особистісних і ситуативних детермінант поведінки суб'єктів ситуації (у тому числі, якщо цими суб'єктами є автор і герої літературного твору).

Ключові слова: психологічні механізми розуміння текстів, стиль роману, механізм децентралізації, механізм емпатії, механізм рефлексії.

\section{Михальчук Наталия, Коваль Ирина. Психологические механизмы пони- мания современных текстов американских писателей}

\section{АННОТАЦИЯ}

Цель статьи - предложить психологические механизмы понимания современных текстов американских писателей через определение стиля романа как сложного и многогранного прочесса.

Для решения поставленных в работе задач использованы следующие теоретические методы исследования: категориальный, структурно-фрункциональный, анализ, систематизация, моделирование, обобщение.

Результаты исследования. Показано, что степень близости вторичного текста к исходному будет зависеть от многих факторов - от уровня понимания человеком исходного текста, ожиданий и установок читателя, уровня читательских интересов, челей чтения. Понимание текста предполагает его расчленение на относительно самостоя(c) Mykhalchuk Nataliia, Koval Iryna

DOI (article): https://doi.org/10.32626/2227-6246.2021-51.121-141 
DOI: https://doi.org/10.32626/2227-6246.2021-51 2021. випуск 51

тельные, независимые относительно фактического содержания отрывки (текстовые элементы) с последующей их перегруппировкой с целью выделения главного и второстепенного, то есть установление иерархии смыслов.

Выводы. Предложены психологические механизмы понимания современных текстов американских писателей. Первым механизмом является механизм децентрации: содержание в сознании субъекта двух противоречивых идей одновременно и при этом - сохранение возможности действовать, анализируя художественные произведения; создание собственных рассказов, решений определенных ситуаций; преодоление личностных эгоцентричных проявлений; толерантное, непредвзятое отношение к мыслям и высказываниям партнеров по коммуникации; преобразование смысла образов, понятий, представлений с учетом собственной эмоционально-когнитивной позиции, точек зрения, поступков, образа жизни других; изменение взглядов и позиций читателя при сопоставлении собственной точки зрения с представлениями и позициями других людей и др. Следующим является механизм эмпатии: характер самостоятельно избранных для психологического анализа произведений художественной литературы (романтические, реалистические, фрилософские); распознавание психических состояний людей, изображенных в произведениях искусства (сюжет, портрет, музыка, картина, ситуация искусства); определение эмоциональных состояний персонажей литературного произведения, партнеров по общению; конгруэнтность поведения в нестандартно-стимулирующих ситуациях или ситуациях когнитивного диссонанса. И, наконеи, последним механизмом является механизм рефлексии: осуществление взаимосвязи элементов литературного произведения в конструктивную систему; обоснование собственного отношения к определенной ситуации, ее участникам, выявление личностных и ситуативных детерминант поведения субъектов ситуации (в том числе, если этими субъектами являются автор и герои литературного произведения).

Ключевые слова: психологические механизмы понимания текстов, стиль романа, механизм децентрации, механизм эмпатии, механизм рефлексии.

Original manuscript received December 30, 2020 Revised manuscript accepted February 08, 2021

(C) Mykhalchuk Nataliia, Koval Iryna DOI (article): https://doi.org/10.32626/2227-6246.2021-51.121-141 